\title{
От дневника погоды к автобиографической прозе: личный архив в культурном пространстве малого города
}

\section{Светлана Александровна Жадовская}

В статье проанализирован личный архив жительницы г. Орлова Кировской области - бывшего уездного центра Вятской губернии. Архив составляют дневники погоды (тетради с подневными записями погоды и комментариями), личные дневники, рукописные альбомы, описывающие жизненные этапы и сферы деятельности автора, ее родственников и земляков, а также альбомы с вырезками публикаций в местной газете. Подобные материалы довольно часто оказываются в поле зрения исследователей, но редко принадлежат одному автору и потому нечасто анализируются в совокупности. В статье делается вывод о том, что многолетние ежедневные записи погоды, генетически связанные, с одной стороны, с традиционным крестьянским укладом, а с другой - с городским летописанием, становятся отправной точкой литературного и публицистического творчества автора. Есть случаи, когда дневниковые записи трансформируются в литературные зарисовки или стихотворения, которые затем публикуются в городской прессе, а впоследствии оказываются на страницах рукописных альбомов. В целом же личный архив Е. С. Гунбиной показывает, как в пространстве малого города поддерживается и передается память местных жителей о самих себе и своем «местожительстве».

Ключевые слова: малый город, Россиия, личный архив, литературная деятельность, дневник погоды, автобиографическая проза, эго-документ, дневники, локальная идентичность

В 2002-2009 гг. студенты и сотрудники филологического факультета Российского государственного педагогического университета им. А. И. Герцена (Санкт-Петербург) ежегодно выезжали в фольклорно-этнографические экспедиции под руководством проф. А. Н. Власова. Целью экспедиций было комплексное фольклористическое обследование бывших уездных центров Русского Севера, которые сегодня стали малыми городами (иногда - селами и поселками городского 
типа) Архангельской, Вологодской и части Кировской областейํ․ 3аписанный материал позволил не только увидеть состояние народной традиции и зафиксировать новые явления, но высветил целый ряд теоретических вопросов и проблем, стоящих перед современной фольклористикой.

Известно, что с конца 20 в. в поле зрения фольклористов, этнологов, антропологов попадают (конечно, не только в российских регионах) многочисленные факты самодеятельного (непрофессионального) индивидуального творчества, в особенности - словесного творчества. Такого рода материалы составляют целый пласт культуры, условно называемой С. Ю. Неклюдовым и рядом других исследователей «наивной литературой» или, в другой терминологии, «третьей культурой»². Значительное число материалов составляют автобиографические документы, или эго-документы, все более активно входящие в научный оборот (Зарецкий 2012; Суржикова 2014). В последние годы их изучение получило толчок благодаря активной работе организаторов и волонтеров проекта «Прожито» по созданию электронного архива дневников на русском языке.

Экспедиции педагогического университета 2000-х гг. показали, что приблизительно с 1960-х гг. в малых городах все более активно ведется литературная деятельность или говоря шире, местными жителями активно создаются письменные нарративы разных форматов и жанров. В музеях, библиотеках и личных собраниях обнаруживаются поэтические сборники отдельных авторов и местных литературных объединений, журналы и альманахи, мемуаристика (воспоминания не только о своей жизни, но и о значимых событиях местной истории) и большое количество краеведческих трудов. Эти тексты могут быть изданы типографским способом, размножены в нескольких экземплярах как самиздат или существовать только в рукописном (машинописном) виде. Лишь очень незначительная их часть попадает в сферу интересов филологов. Между тем, по мнению М. Л. Лурье, «регулярность этих находок, во-первых, заставляет наглядно убедиться в том, что спонтанное художественное творчество [...] не культурная аномалия, а весьма распространенное явление, составляющее одну из социокультурных реалий постликбезовской эпохи. Во-вторых, случайно попадающие таким образом в руки собирателей

\footnotetext{
${ }^{1}$ В настоящее время работа продолжается в отделе русского фольклора Института русской литературы (пушкинский Дом) РАН.

${ }^{2}$ См., например, сб.: Неклюдов 2001; Неклюдов 2009; Поздеев 2000.

${ }^{3}$ http://prozhito.org. Некоторые документы опубликованы и продолжают публиковаться. См., например: Белоусов 2016; Измайлов 2020.
} 
произведения, а порой и целые архивы сельских писателей составляют ценный материал по народному сочинительству “для себя" и “на случай”» (Лурье 2007: 5-9).

Вопрос соотношения «устности» и «книжности» в непрофессиональном словесном творчестве ставился не раз. Так, В. С. Бахтин, записав летом 1959 г. в костромской деревне ряд песен авторства местных жителей, отмечал, что песни эти «оторвались от авторов, вошли в народный обиход. Активная их жизнь продолжалась, по-видимому, всего несколько лет, пока поколение, создавшее и воспринявшее их, не вошло в пору зрелости. В пассивной же форме они живут вот уже более полувека» (Бахтин 1976: 230). В социальном пространстве современного малого города вряд ли стоит говорить об усвоении традицией (фольклоризации) авторских текстов. Важным оказывается другое: личное творчество самодеятельного автора, во многом ориентируясь на книжно-литературную традицию, функционирует по принципу ритуализованной культурной практики. Этим объясняется «похожесть», даже отмечаемая многими клишированность текстов, созданных в разных местах, но воспроизводящих один и тот же «авантекст» (термин С. Ю. Неклюдова).

Важно подчеркнуть, что письменные тексты жителей малых городов объединены так называемым «локальным содержанием», которое составляет их общую основу. Все они, хотя и в разной степени, «привязаны» к городу (селу), в котором создаются. Справедливо отметил В. С. Бахтин: «Если же локальное содержание, групповое сознание сделать признаком, определяющим жанр, род, то сюда могут быть отнесены и многие другие произведения, не только песни-дразнилки. И все эти произведения будут как бы пограничными между литературой и фольклором, между индивидуальным и коллективным творчеством» (Бахтин 1976: 233).

По точному выражению архангельского литературоведа и писателя Е. Ш. Галимовой, «большинство [...] северных писателей занимаются не самовыражением (не бесконечным анализом своих душевных состояний), а жизнью: современниками и собой в контексте эпохи» (Доморощенов 2008: 19, Выделено мной. - С. Ж.). Более того: как представляется, многочисленные образцы литературной практики жителей малых городов, независимо от их художественной составляющей и жанров, в совокупности образуют локальную культурную практику, призванную репрезентировать местную коллективную идентичность. Литературная деятельность, выраженная и в стихах, и в эгодокументах, и в краеведческих очерках, становится для местных жителей важным фактором сохранения памяти о себе (своей семье) и о своем «местожительстве». 
В нашей статье будет проанализирован личный архив одного автора, являющийся редким случаем сочетания письменных текстов разного типа. Евгения Сергеевна Гунбина (род. в 1932 г.) - жительница г. Орлов (в советское время - Халтурин) Кировской области (бывш. Вятской губернии). Мы покажем, как в ее письменном наследии сосуществуют и пересекаются различные типы текстов, и зачастую тексты одного типа (жанра) становятся источником и материалом для других. Рассмотренный комплексно, архив Е. С. Гунбиной представляет значимый в локальном сообществе факт литературной деятельности, фиксирующей память местного жителя «о времени и о себе» (В. В. Маяковский).

Скажем несколько слов о месте, где живет автор архива. Город Орлов расположен на правом берегу р. Вятки, его название впервые упоминается в документах в 1459 г., а первое поселение (городище) относится, согласно краеведческим трудам, к 12-13 вв. В ходе административных преобразований Екатерины II в 1780 г. Орлов получил статус уездного города Вятского наместничества (с 1796 - Вятской губернии). В 1923-1992 гг. назывался Халтурин в честь революционера-народовольца Степана Халтурина (1856-1882), родившегося в деревне неподалеку от Орлова. С 1993 г. вновь носит имя Орлов и является центром Орловского района Кировской области.

Держатель и автор архива Евгения Сергеевна Гунбина ${ }^{4}$ родилась в п. Пижма Горьковской (ныне Нижегородской) области, закончила Кировский педагогический институт по специальности «Русский язык и литература», работала преподавателем-словесником в школе п. г. т. Свеча Свечинского района Кировской области и там же - секретарем райкома комсомола, затем преподавала в педагогическом училище г. Халтурин. В 2005 г. она, ветеран педагогического труда на пенсии, продолжала жить в известном всем местным жителям «учительском доме», построенном в советское время специально для учителей.

Как многие учителя, Евгения Сергеевна - заметный и значимый в небольшом городе человек: в течение 26 лет преподавала в местном педагогическом училище (колледже), вела общественную работу, о ней опубликованы статьи в местной прессе. Она хорошо знакома землякам не только преподавательской деятельностью: много лет Евгения Сергеевна, как и ее родители, играла в городском народном театре, вплоть до последнего времени принимала живейшее участие в городских мероприятиях. Известно местному сообществу и ее ли-

\footnotetext{
${ }^{4}$ Знакомство участников экспедиции с Евгенией Сергеевной Гунбиной произошло в июле 2005 г.
} 
тературно-публицистическое творчество: рассказы-воспоминания, очерки, миниатюры, заметки и стихи Е. С. Гунбиной, члена орловского литературного объединения «Вдохновение», довольно часто появлялись на страницах местной «Орловской газеты» конца 1990-х-2000-х годов, напечатаны они и в самиздатовских сборниках.

Уникальность личного архива Евгении Сергеевны заключается именно в редком собрании разных по жанру текстов, отдельные образцы которых обнаруживаются во многих российских провинциальных городах. Это дневники погоды (тетради с подневными записями погоды и комментариями), личные дневники, рукописные альбомы, зафиксировавшие жизненные этапы и сферы деятельности самой Е. С. Гунбиной, ее родственников и земляков, а также альбомы, где собраны публикации автора в местной газете. Дневники погоды и личные дневники велись в обычных «общих» тетрадях, альбомы оформляла сама Евгения Сергеевна.

По ее словам, привычка вести личные записи родилась именно из дневника погоды, начатого еще в 1980-е годы и постоянно заполняемого в течение многих лет. При отъездах из Орлова Евгения Сергеевна продолжала заполнять дневник в соответствии с погодой той местности, где находилась.

С одной стороны, традиция фиксировать погоду восходит еще к русскому летописанию, но в летописях отмечались, как правило, явления природы, маркируемые как более или менее аномальные: «Том же льть вода бяше велика в Волховь, а сньгъ лежа до Яковля дни» (Насонов 1950: 21). Подобные факты (град, ранний или поздний ледостав/ледоход) становились сюжетами исторических преданий и включались в житийный канон (скажем, широко распространено на Русском Севере предание об «огненной туче» в составе рассказов о житии Прокопия Устюжского 5 ). С другой стороны, ежедневные записи погоды, круглогодичные метеорологические наблюдения были частью традиционного русского крестьянского быта и издавна известны этнографической науке. Так, среди документов Архива Императорского Русского географического общества, описанных Д. К. Зелениным в 1914-1916 гг., такие рукописи были отмечены в Архангельской, Владимирской, Вологодской, Волынской, Воронежской, Вятской, Казанской, Нижегородской, Новгородской, Олонецкой, Пермской и других российских губерниях, т. е. более или менее систематические наблюдения за погодой были присланы с середины 19 и до начала 20 века практически со всей страны ${ }^{6}$. Метеорологические за-

\footnotetext{
${ }^{5}$ Подробнее см.: Власов 2010.

${ }^{6}$ Подробнее см.: Жадовская 2019.
} 
писи были одним из пунктов этнографических программ Русского географического общества ${ }^{7}$, но вместе с тем именно тогда, по словам А. Ф. Некрыловой, наблюдения за миром природы были свойственны не только русскому крестьянину, но и городским жителям: «...подавляющее большинство русского населения, включая поместных дворян и жителей уездных городов, смотрело на окружающий мир глазами крестьянина, разделяя его точку зрения на природные явления, годовой и суточный циклы» (Некрылова 2009: 5). Наблюдения за метеорологическими явлениями позволяли крестьянину предсказывать погоду (на чем основаны народные приметы о погоде, гадания и другие календарные обрядовые циклы) и образовали целый пласт традиционных представлений русского народа. К настоящему времени в различных населенных пунктах обнаружены и опубликованы дневники, содержащие наблюдения за погодой. Таковы, например, «Дневник тотемского мещанина А. А. Замараева (1906-1922)» (Замараев 1995: 245-517), «Дневные записки» усть-куломского крестьянина И. С. Рассыхаева (1902-1953)» (Рассыхаев 1997) и др.

Отметим, что ко второй половине 20 в. ведение дневников погоды стало еще и частью школьной системы: вести ежедневные наблюдения за основными метеорологическими параметрами в месте проживания предлагалось ученикам на уроках природоведения/географии. Именно школьный язык описания обнаруживается в дневниках E. С. Гунбиной (это и явления, отмечаемые в дневнике: температура воздуха, облачность, осадки, - и используемые условные обозначения видов осадков). Интересно, однако, что вероятная детская привычка вести дневник переросла в позднем возрасте в записи погоды как форму дискурсивной практики. Л. Я. Рахманова, анализируя многолетние дневники погоды, ведущиеся жителями приобских поселков Томской области, приходит к выводу о том, что «жанр дневника погоды, формируемый сельской интеллигенцией, [...] представляет собой переходную форму между дневником наблюдений и летописью жизни села, в котором природные аспекты тесно связаны с социальными» (Рахманова 2019: 147). Исследовательница отмечает, что «на страницы дневников погоды прорываются иные смыслы, события, впечатления, выводы и прогнозы, ломающие канонический протокол наблюдений» (Там же: 137).

Можно, думается, говорить, что глубинная связь календарного и жизненного циклов, присущая традиционному крестьянскому миро-

\footnotetext{
${ }^{7}$ Одной из первых программ созданного в 1845 г. Императорского Русского географического общества были «Правила для собирания сведений, служащих определением климата». Подробнее см.: Васкул 2019.
} 
воззрению и становящаяся фундаментом для создания письменных текстов, трансформируется в конце 20 в. в особый вид письменного творчества - дневник погоды как способ говорения о себе и в большой степени - о себе в движении времени. Наблюдения за жизнью природы становятся поводом к художественному осмыслению действительности, к самовыражению и, как следствие, - к литературному творчеству.

Этот тезис хорошо иллюстрируется содержанием дневников погоды Евгении Сергеевны Гунбиной. Все тетради называются почти одинаково: «Наблюдения за (вятской) природой и запись некоторых событий». Частично они представляют собой традиционные таблицы с усвоенными, по-видимому в школе, условными обозначениями (снег, дождь, t). В некоторых же графах даны дополнительные комментарии, фиксирующие частную жизнь автора. Так, запись от 15 июля 1986 г. свидетельствует:
«утро $+16^{\circ}$
Облачность
кратковрем<енные> дожди, не знаешь, как высушить белье t воды в Вятке $+18 »$.

3 января 1994 г.:

«**8 тепло
$-1-4^{\circ}$
снег

Приехала Нина ${ }^{9} »$.

4 января того же года:

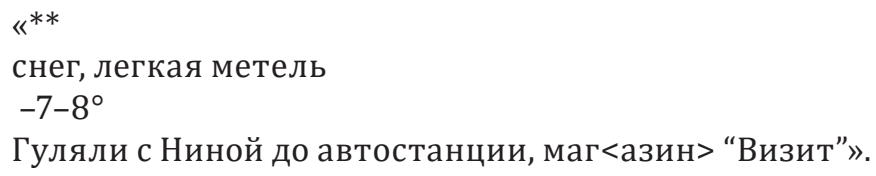

6 января того же года:

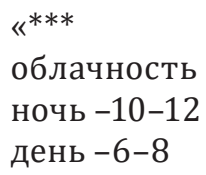

\footnotetext{
${ }^{8}$ Условное обозначение снега. Далее ${ }^{* * *}$ - по-видимому, сильный снег.

${ }^{9}$ Дочь Е. С. Гунбиной, живущая в г. Ижевске.
} 
В отдельных графах дневника погоды присутствуют также вклеенные вырезки из центральных (столичных и областных) газет с прогнозами погоды и комментариями автора (например, что из прогноза подтвердилось, а что нет); часть записей сопровождается вырезками сообщений о погодных аномалиях на территории СССР (например, в Грузии: о внезапном понижении температуры рассказывает заметка «Июньский снег», 1986 г.). Нередко Е. С. Гунбина создает среди ежедневных записей целостное описание погоды за какой-либо месяц (см. иллюстрации к статье). Интересно, что позже мы можем найти следы этого описания в заметке, опубликованной в местной Орловской газеme - как миниатюру-описание природы. Отметим, кстати, что газетные вырезки с публикациями Евгении Сергеевны составляют целый «творческий» альбом, созданный автором. Таким образом, записи в дневнике погоды через художественно осмысленное описание и в их связи с личными фактами становятся литературным текстом.

Традиция погодных записей, по утверждению автора, существовала в нескольких поколениях ее семьи и была унаследована ею как традиционная семейная практика, не нагруженная в настоящее время большим практическим (в первую очередь сельскохозяйственным и прогностическим) смыслом. Ежедневно записывая погоду, делая обобщения за неделю или месяц, Е. С. Гунбина, по ее словам, не обращалась к записям прежних лет для сравнения и/или предсказания погоды. Эта практика была для нее скорее упражнением интеллектуального характера, «нагрузкой для ума», позволяющей ежедневно приобщаться к созданию письменного текста, сохраняя тем самым и семейную традицию. Наблюдения за природой естественным образом связываются с частной жизнью Евгении Сергеевны, и запись погоды одновременно становится дневниковой записью. Не случайно тетрадь дневника погоды за 2000-2005 гг. носит название «Наблюдения за вятской природой и запись некоторых событий». (Выделено мной. - С. Ж.).

Кроме дневников погоды, в архиве Евгении Сергеевны хранятся личные дневники (нам удалось познакомиться с материалами за 1995, 1997, 1998, 2000-2002 гг.), исследование своей родословной, очерки и эссе о земляках, воспоминания о военном детстве, о народном театре в Орлове и др. Занимая промежуточное положение между краеведческими трудами и мемуаристикой, произведения Е. С. Гунбиной не являются ни тем, ни другим. Это скорее современный городской вариант рукописных альбомов - авторские сочинения на выбранную тему, написанные от руки или распечатанные на принтере и оформленные в рукопись с вклеенными в нее в качестве иллюстраций подлинными фотографиями и документами. Назовем некоторые из таких аль- 
бомов: «Любимая профессия» (воспоминания о маме-учительнице, о собственном пути в педагогическую профессию, о студенческой юности и учениках, о юбилее педагогического училища; записи дополняются газетными заметками о школьном литературном кружке под руководством автора, о ней самой - от ее бывших учеников и т. д.), «Военное детство» (о детских годах, пришедшихся на конец 1930-х-1940-е гг., альбом 1998 г.), «Комсомольская юность моя» (альбом 1998 г. к 80-летию ВЛКСМ: о комсомольской юности и работе в райкоме комсомола в п. Свеча Орловского района), «Судьбы земляков» (2001 г., об «интересных вятских людях»-современниках автора), «Театр в моей жизни» (2003 г., о родителях, познакомившихся на сцене народного театра п. Пижма Горьковской области, о посещении театров Москвы, Тамбова, Кирова, о народном театре Орлова).

Личные дневники Е. С. Гунбиной, с которыми мы познакомились, представляют читателю повседневную жизнь учительницы-пенсионерки конца 1990-х-начала 2000-х гг. с ее бытовыми и финансовыми тяготами и простыми радостями вроде встреч с подругами-коллегами, самостоятельно сделанным к юбилею ремонтом и письмами от дочери. Одновременно на страницах дневников предстает постоянно рефлексирующая личность автора. Так, январь 1995 г. открывается записью:

«Все-таки я - человек умственного труда. Все дела по самообслуживанию: готовка еды, уборка, топка печи, стирка и т.п. - не главное. Хочется читать, писать, общаться с людьми. Вот и буду здесь «выпускать пар...».

В дневнике 2000 г.:

«Вот И. Бунин говорил, что самая реальная жизнь просматривается не в литературных произведениях, а в дневниках. И правда!» ${ }^{10}$

Личные дневники Е. С. Гунбиной часто имеют заголовок «Записи для себя и на память». В дневник записывается то, что спровоцировало рождение мысли - от телевизионной новости до покупки нового, широко рекламируемого майонеза. Механизм «записывания на память» в этом случае таков: фиксируется факт, примечательный для автора, он подтверждается материальным свидетельством (вырезанная и вклеенная статья из центральной или местной газеты, этикетка от майонеза/халата, письмо дочери или подруги и т. д.), после которого следует размышление или высказывание «по поводу». Газетная

10 Личный архив Е. С. Гунбиной. 
статья «Случай с тортиком» стала толчком к длинной дневниковой записи, охватывающей почти всю биографию автора. А желание запечатлеть разные стороны жизни г. Орлова (и на его примере - всей российской провинции) выразилось в создании очерка «А есть и такие... Орловские пьяницы», в которой нелицеприятно описаны ближайшие соседи автора. Заканчивается очерк фразой: «Не хочу о них говорить больше!»

Архив Гунбиной интересен исследователю, повторим, как единственный пока известный нам пример комплекса разножанровых письменных текстов одного автора. Такая совокупность авторских нарративов позволяет проследить сам процесс создания текста. Так, запись из дневника погоды нередко становится основой для зарисовки-миниатюры, а очерки из альбомов трансформируются в публикации в местной газете. Например, очерк «Музыкальные души» из альбома «Судьбы земляков» (2001) был написан спустя полгода после смерти жителя г. Орлова В. Ф. Шалагинова, баяниста, директора детской музыкальной школы. Через полгода немного переработанный текст был опубликован в «Орловской газете» уже для всех жителей города (Гунбина 2001) ${ }^{11}$. Небольшая заметка «Эх ты, баня русская, да разгони печаль!», напечатанная в газете в 2003 г. (Гунбина 2003), в основе своей имеет рассказ «Русская баня», написанный в 1998 г. и помещенный в альбоме «Пережитое, родное и близкое». Такие примеры не единичны.

При изучении культурного пространства малого города основополагающим становится понятие памяти. Поэзия и проза, записки и мемуары местных жителей создаются, на наш взгляд, не для продуцирования некоего нового смысла, а для поддержания идентичности местных жителей как представителей локального сообщества. Обратимся еще раз к формулировкам автора: она ведет записи «для себя и на память», «записи на память и для души». По свидетельству Е. С. Гунбиной, погодные записи и дневники она хранила, но не перечитывала с момента создания. Однако дневники и даже альбомы Е. С. Гунбиной принципиально диалогичны. Так, в альбомах установка на диалог реализуется в сочетании газетных вырезок с письмами родственников (реакция на напечатанное), с рукописными комментариями, рассказывающими предысторию описанного, с рассуждениями и размышлениями (см. иллюстрации). Даже записи в личных дневниках содержат элементы диалога, латентно рассчитаны на адресата.

\footnotetext{
${ }^{11}$ Ксерокопия опубликованной статьи расположена в альбоме рядом с исходным очерком.
} 
Так, автор редактирует некоторые записи (это видно по следам правки), уточняя их, иногда сразу поясняет, комментирует. Например:

«И все время мне выпадает роль слушателя, сопереживателя, успокоителя. Лены, Лидии Кондратьевны (мамы Саши Бердникова)» ${ }^{12}$.

Помещая в дневник вырезанную из газеты фотографию старого орловского кинотеатра, Е. С. Гунбина делает в примечание: «Мы его с Ниной еще застали». Такие примеры не единичны, а типичны для дневников Е. С. Гунбиной. Созданные в непрерывном внутреннем общении с семьей и друзьями, ее тексты не замыкаются в рамках «семейной письменности» (Разумова 2005) и выходят за пределы семейно-родственного круга. Они создаются «на память» не только для себя, но во многом и о себе, о месте своего обитания и других его жителях в определенный отрезок времени. Таким образом, личный архив выступает хранилищем и репрезентацией запечатленной памяти, что подтверждается спектром тематик, которые творчески осмысляются автором архива. В конечном итоге записи и альбомы Е. С. Гунбиной в своей совокупности позволяют не только поставить вопрос, но и в какой-то степени ответить, каков механизм создания и функционирования того множества любительских текстов, которые составляют значительный пласт национальной культуры нашего времени. Зафиксированные в поэтических и прозаических (литературно-публицистических, мемуарных, краеведческих и пр.) текстах крупные и мелкие события городской жизни, «портреты» земляков и даже записи местной погоды становятся фактами «большой истории» страны и в качестве таковых являются определяющим для местных жителей фактором локальной идентичности.

\section{Библиография}

Бахтин, В. С. (1976). Один из неучтенных песенных жанров (к вопросу об индивидуальном творчестве в фольклоре). Русский фольклор: Историческая жизнь народной поэзии, 16, 227-235.

Белоусов, Н. М. (2016). Дневник токаря Белоусова (1937-1939 г2.). Б/м.

Васкул, А. И. (2019). Из истории Архива Русского географического общества. В:

Зеленин, Д. К. Описание рукописей Ученого архива Императорского Русского географического общества. Вып. 4 / подг. текста и вступ. ст. А. И. Васкул (VIXXII). Санкт-Петербург.

\footnotetext{
${ }^{12}$ Выделено мной. - С. Ж.
} 
Власов, А. Н. (2010). Житийные повести и сказания о святых юродивых Прокопии и Иоанне Устюжских. Санкт-Петербург.

Гунбина, Е. (2001). Памяти талантливого человека. В Орловская газета, 17 мая 2001 г., 4.

Гунбина, Е. (2003). Эх ты, баня русская, да разгони печаль! В Орловская газета, 1 февраля 2003 г., 1.

Доморощенов, С. (2008). Интервью с Е. Ш. Галимовой. В Правда Севера, 13 марта 2008 г., 19.

Жадовская, С. А. (2019). Предметно-тематический указатель (2019). В: Зеленин, Д. К. Описание рукописей Ученого архива Императорского Русского географического общества. Вып. 4 / подг. текста и вступ. ст. А. И. Васкул (1667-1694). Санкт-Петербург.

Замараев, А. А. (1995). Дневник тотемского мещанина А. А. Замараева. 19061922 / публ. В. В. Морозова, Н. И. Решетникова. Москва.

Зарецкий, Ю. П. (2012). История субъективности и история автобиографии: важные обновления. В Неприкосновенный запас, 3. https://magazines.gorky. media/nz/2012/3/istoriya-subektivnosti-i-istoriya-avtobiografii-vazhnyeobnovleniya.html (25. 05. 2021).

Измайлов, К. Ф. (2020). Дневник алтайского крестьянина К. Ф. Измайлова (1923-1941 г2.): В 2 т. / науч. ред. А. Байкалова. Б/м.

Лурье, М. Л. (2007). Деревенский поэт Ю. В. Тимофеев. В Живая старина, 1, 5-9.

Минаева, А. П. (2009). До и после литературы: тексты «наивной словесности» / сост. А. П. Минаева. Москва.

Насонов, А. Н. (1950). Новгородская первая летопись старшего и младшего изводов / под ред. и с предисл. А. Н. Насонова. Москва; Ленинград.

Неклюдов, С. Ю. (2001). «Наивная литература»: исследования и тексты (сост.). Москва.

Некрылова, А. Ф. (2009). Традиционный русский календарь. В Некрылова А. Ф. Традиционный русский календарь на каждый день и для каждого дома (522).

Поздеев, В. А. (2000). «Третья культура»: проблемы формирования и эстетики. Москва.

Разумова, И. А. (2005). Письменные традиции современной семьи: проблемы собирания и изучения. http://www.ruthenia.ru/folklore/rasumova1.htm (25. 05. 2021).

Рассыхаев, И. С. (1997). "Дневные записки» усть-куломского крестьянина И. С. Рассыхаева (1902-1953) / вст. ст. и подг. текста Т. Ф. Волковой и В. В. Филипповой, коммент. В. А. Семенова. Москва.

Рахманова, Л. Я. (2019). Сельские дневники погоды и промысловые журналы как репрезентация гибридных форм взаимодействия науки и локальных сообществ. В Сибирские исторические исследования: Языкознание и литературоведение, 4, 134-161.

Суржикова, Н. В. (2014). История в эго-документах: исследования и источники (сост.). Екатеринбург. 


\section{ПРИЛОЗи}

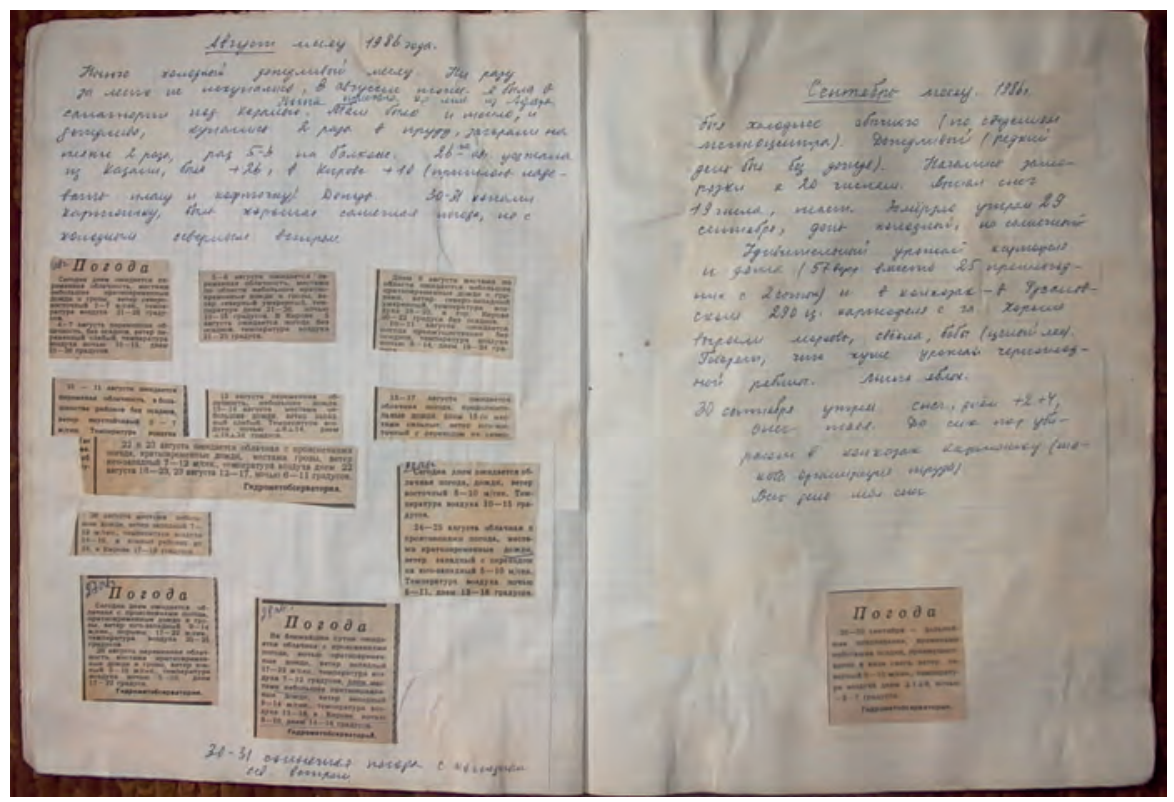

Сл. 1. Дневник погоды Е. С. Гунбиной, 1986 г.

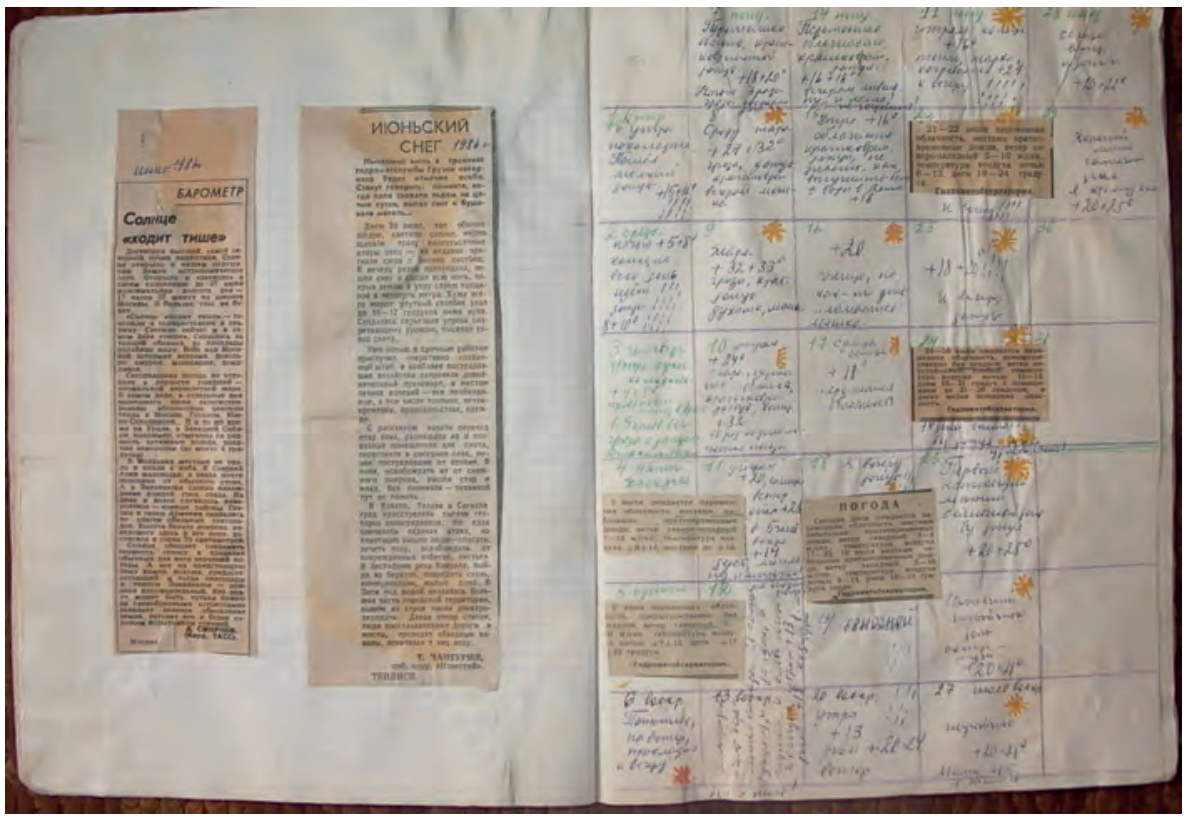

Сл. 2. Дневник погоды Е. С. Гунбиной с комментариями, 1986 г. 


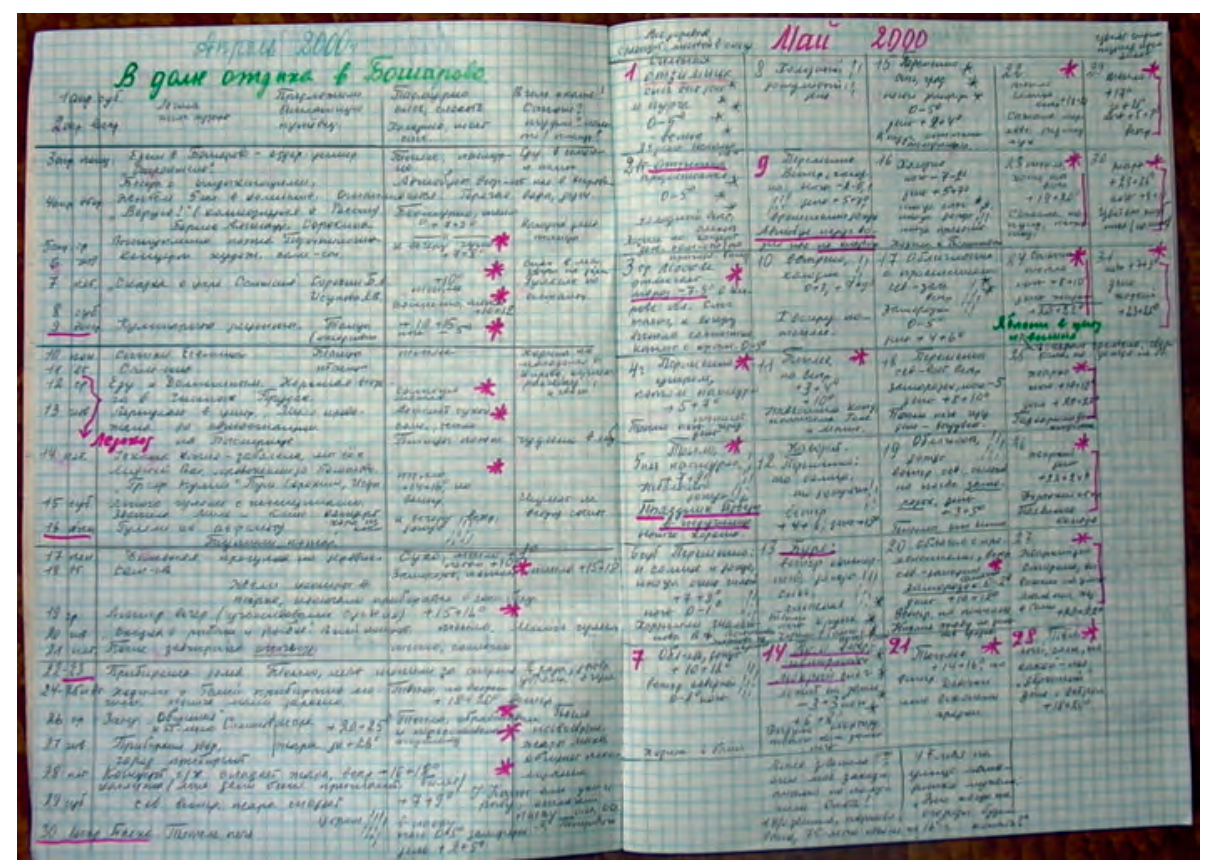

Сл. 3. Страницы дневника погоды и некоторых событий, 1986 г.

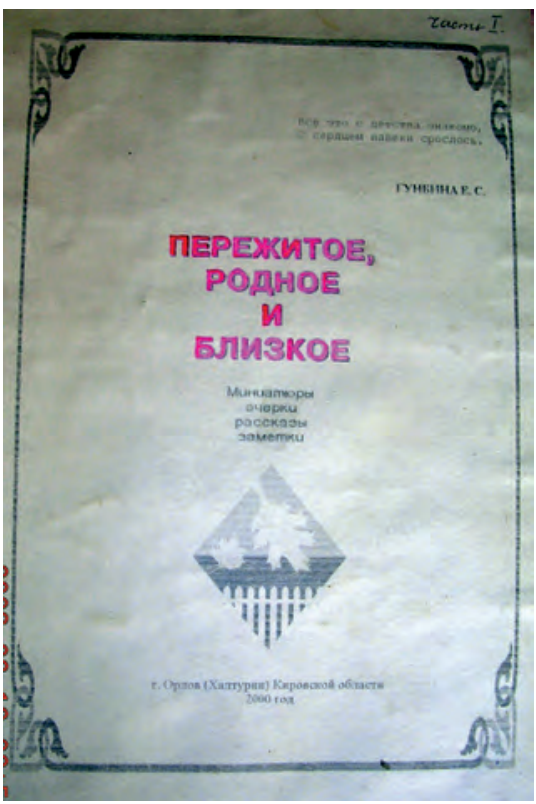

Сл. 4. Пережитое, родное и близкое, обложка альбома 


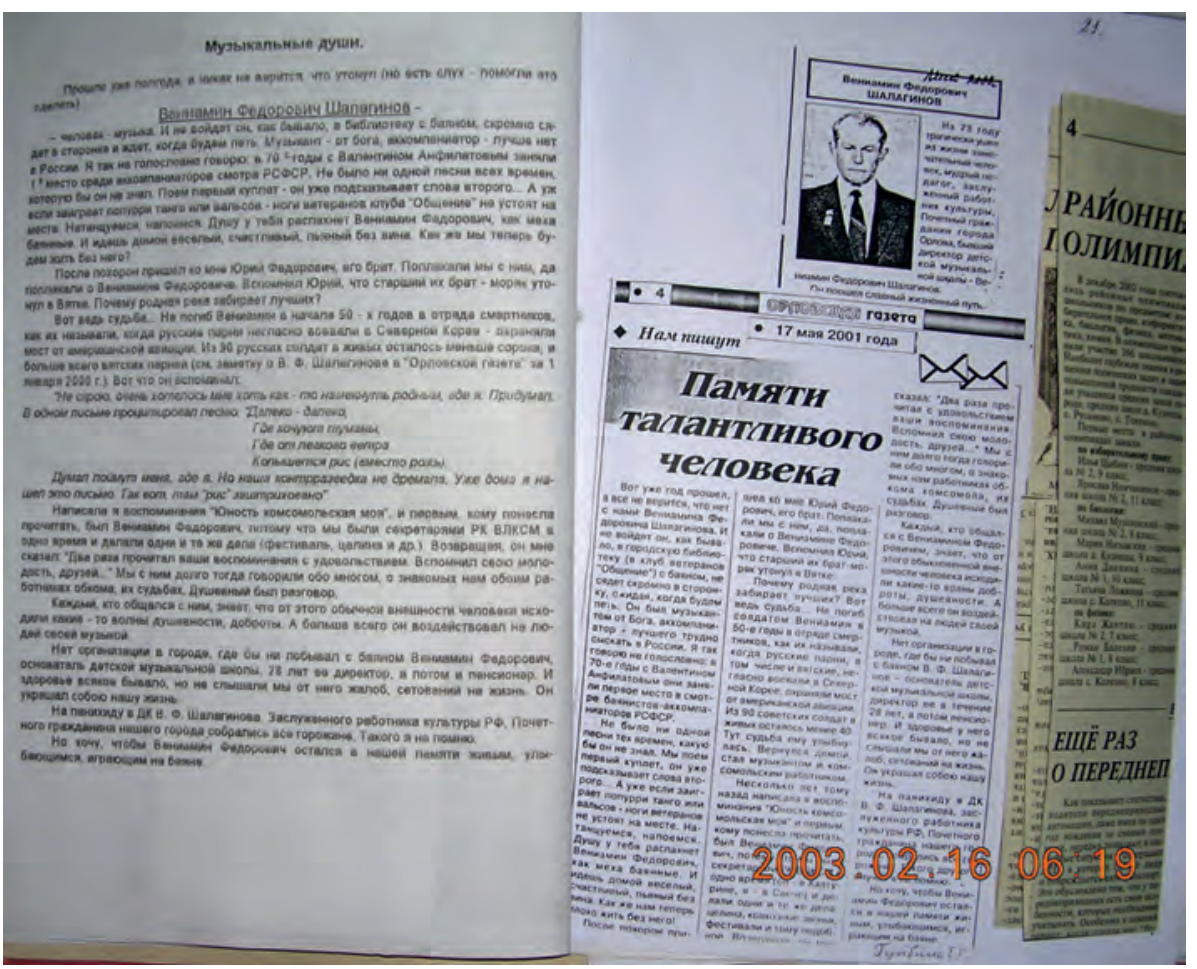

Сл. 5. Два очерка о В. Ф. Шалагинове

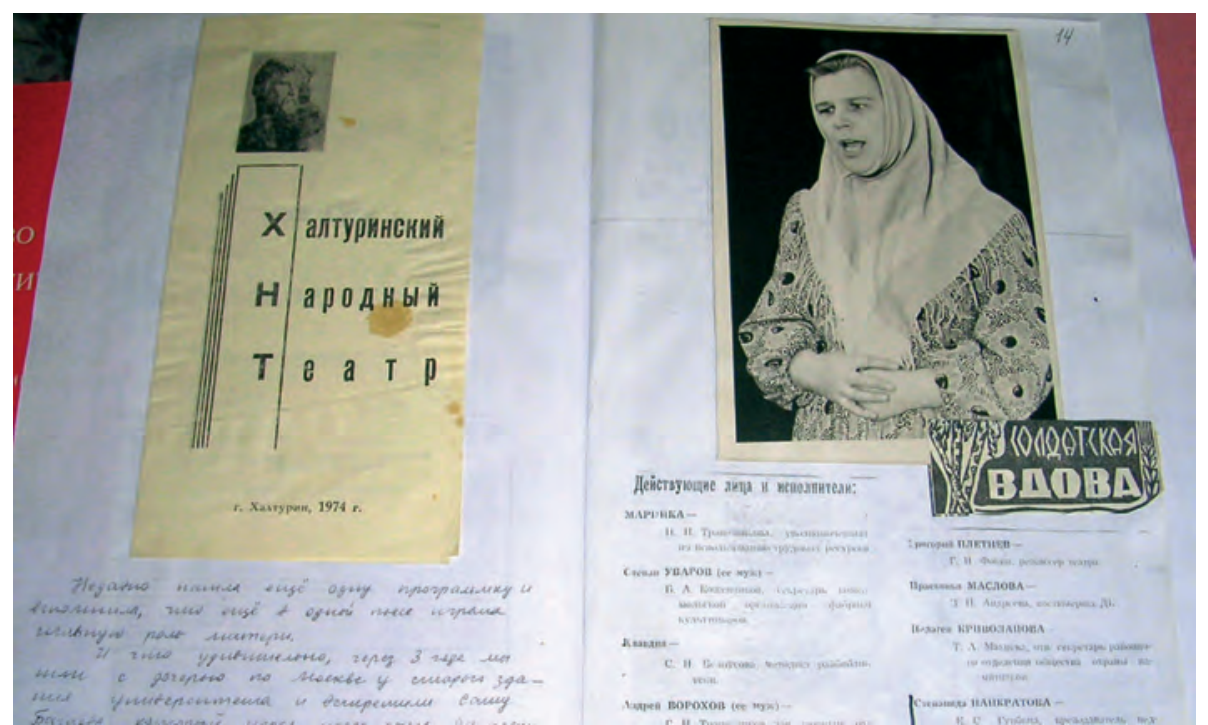

Сл. 6. Страницы альбома Театр в моей жизни (на фото: Е. С. Гунбина) 


\title{
Источники иллюстрации
}

Фото автора статьи.

\author{
From the Weather Diary to Autobiographical Prose: \\ Personal Archive in the Cultural Space of a Small Town
}

\author{
Svetlana A. Zhadovskaya
}

\section{Summary}

The article analyzes the personal archive of a resident of the town of Orlov of the Kirov region, Russia - the former district center (center of uyezd) of the Vyatka province. The archive consists of weather diaries (daily weather records and comments), personal diaries, handwritten albums describing the life stages and activities of the author, her relatives and fellows, as well as albums with publications in the local newspaper. Such material quite often comes to the attention of researchers, but rarely belongs to one author and therefore is rarely analyzed as a whole. It is concluded in the article that long-term daily weather records that are genetically related with the traditional peasant way of life on one hand, and with the tradition of town chronicles on the other, become the starting point of the author's literary work. There are cases when diary entries are transformed into literary sketches or poems, which are then published in the town press, and subsequently appear on the pages of handwritten albums. In general, the personal archive of E. S. Gunbina shows how the memory of local residents about themselves and their "place of residence" is maintained and transmitted in the space of a small town.

Keywords: small town, Russia, personal archive, literary activity, weather diary, autobiographical prose, ego document, diaries, local identity

\section{Од дневника о временским приликама до аутобиографске прозе: лични архив у културном простору малог града}

\section{Светлана А. Жадовска}

\section{Резиме}

У тексту се анализира лични архив житељке града Орлова у Кировској области у Русији, бившег административног центра Вјатске губерније. Архив чине дневнички записи о временским приликама (свеске са свакодневним 
описима временских прилика и коментарима), лични дневници, рукописни албуми који илуструју животна раздобља и сфере делатности ауторке, њених рођака и земљака, као и албуми са исечцима из локалних новина. Долази се до закључка да вишегодишњи свакодневни описи временских прилика који су, с једне стране, суштински повезани са традиционалним сеоским начином живота, а с друге - са градским летописним традицијама, представљају полазиште ауторкиног стваралаштва. Приметни су случајеви у којима се дневнички записи трансформишу у књижевне цртице или стихове који се потом објављују у градској штампи, да би се затим нашли на страницама рукописних албума. Посматран као целина, лични архив J. С. Гунбине илуструје како се у малој градској средини одржава и преноси сећање мештана на саме себе и на своје „пребивалиште“.

Кључне речи: варошица, Русија, лични архив, књижевна делатност, дневник временских прилика, аутобиографска проза, его-документ, дневници, локални идентитет

Светлана Александровна Жадовская

Канд. филол. наук, научный сотрудник

Отдела русского фольклора Института

русской литературы (Пушкинский Дом) РАН

Санкт-Петербург, Россия

Е-пошта: svet.cher@gmail.com

Примљено: 7. 12. 2020.

Прихваћено: 15. 5. 2021. 